\title{
A Middle Caddo Period Cemetery (41FK97/139) on Big Cypress Creek in Franklin County, Texas
}

Timothy K. Perttula

Heritage Research Center, Stephen F. Austin State University

Bo Nelson

Heritage Research Center, Stephen F. Austin State University

Follow this and additional works at: https://scholarworks.sfasu.edu/ita

Part of the American Material Culture Commons, Archaeological Anthropology Commons, Environmental Studies Commons, Other American Studies Commons, Other Arts and Humanities Commons, Other History of Art, Architecture, and Archaeology Commons, and the United States History Commons

Tell us how this article helped you.

This Article is brought to you for free and open access by the Center for Regional Heritage Research at SFA ScholarWorks. It has been accepted for inclusion in Index of Texas Archaeology: Open Access Gray Literature from the Lone Star State by an authorized editor of SFA ScholarWorks. For more information, please contact cdsscholarworks@sfasu.edu. 


\section{A Middle Caddo Period Cemetery (41FK97/139) on Big Cypress Creek in Franklin County, Texas}

\section{Creative Commons License}

\section{(c) (1) (8)}

This work is licensed under a Creative Commons Attribution-NonCommercial 4.0 International License 


\title{
A Middle Caddo Period Cemetery (41FK97/139) on Big Cypress Creek in Franklin County, Texas
}

\author{
Timothy K. Perttula and Bo Nelson
}

\section{INTRODUCTION}

In the early 1990s, an ancestral Caddo habitation site and cemetery was reported to the junior author in the Big Cypress Creek valley in Franklin County in East Texas (Figure 1) by a local collector. The site is in an area of other known ancestral Caddo cemeteries, including the Bruce J. Connally Farm (41FK5) and the P. G. Hightower Farm (41FK7) (Thurmond 1990:158-159). In this article we summarize the available information about this important but still little known ancestral Caddo site.

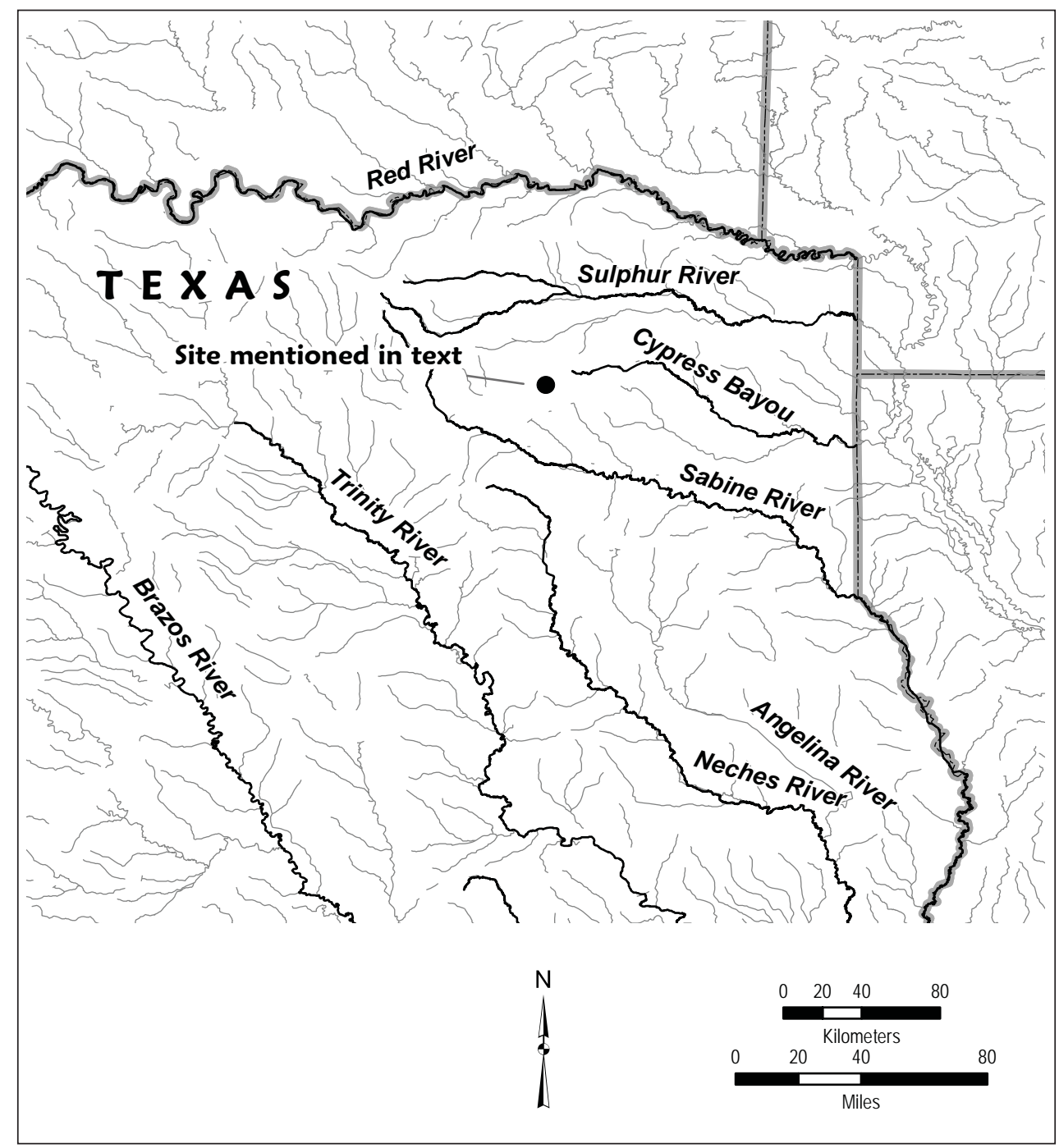

Figure 1. The location of the ancestral Caddo site discussed in the text in East Texas. 


\section{Available Site and Cemetery Information}

The site is on a large upland landform (400-4240 ft. amsl) overlooking the north and west sides of the Big Cypress Creek floodplain. The known extent of the archaeological deposits at the site, based on the distribution of artifacts on the surface and in gopher mounds, is ca. 350 × $350 \mathrm{~m}$ in size or ca. 30 acres (Figure 2).

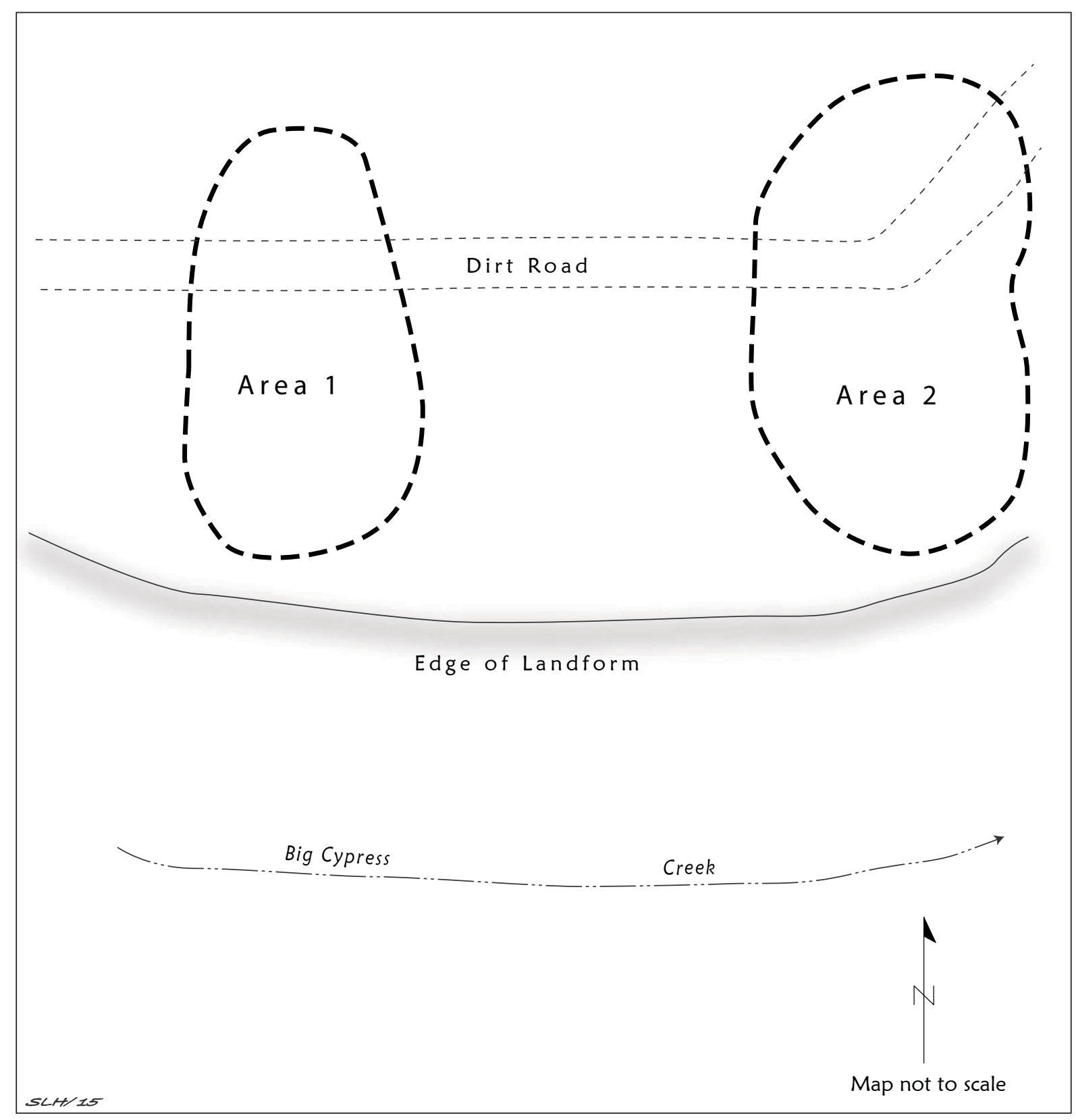

Figure 2. Map of Areas 1 and 2 at the ancestral Caddo site discussed in the text.

Area 1 at the site had both arrow points and dart points, as well as eight ancestral Caddo burials. Area 2 may have had midden deposits, and two ancestral Caddo burials were known to have also been discovered in this part of the site. The burials in Area 1 were in a single north-south row, in east-west oriented graves where the deceased had been laid out in an extended supine position; based on the size of the graves and the inclusion of miniature ceramic vessels in two of the burials, six burials in Area 1 were those of adults and the other two were children. Two of the burials had an ash lining in the grave pit and another was lined with ferruginous sandstone rocks. 
This ancestral Caddo site was not officially recorded until April 1997 when the western part of the site was investigated as part of proposed SH 37 improvements by the Texas Department of Transportation. It was noted during the time the site was first recorded that there was a $13 \mathrm{~m}$ long looter trench in this part of the site. A single engraved bottle sherd was collected from the site at that time: the sherd had both vertical and horizontal engraved lines, as well as one vertical engraved line with open engraved pendant triangles. In April 2010, the eastern portion of the site was recorded, and assigned 41FK139 as its trinomial, the assumption being made that though the western and eastern parts of the site were on the same upland landform, they must be separate and unrelated sites. This part of the site was bisected by the right-of-way of the Keystone XL pipeline (Carpenter et al. 2010). The site form does not mention the occurrence of midden deposits or burial features, but based on the size of the pipeline right-of-way that was examined, it appears in any event to be the case that the known extent of the collector-excavated cemetery area is outside of the Keystone XL pipeline right-of-way; whether there are additional ancestral Caddo burials in the pipeline right-of-way has not been ascertained. Following Texas Archeological Research Laboratory procedures when an archeological site has received two separate trinomials (e.g., because the overall extent of the site was not assessed at the time) when in fact both parts of the site are actually encompassed within a single larger site, the lower assigned trinomial —in this case, 41FK97-is to be used when referencing the site's trinomial (Jean Hughes, June 2015 personal communication to the senior author).

\section{Ceramic Vessel Funerary Offerings}

A number of ceramic vessels ( $\mathrm{n}=19)$ were placed in the graves in Area A at the site as funerary offerings; this is a mean of 2.4 vessels per grave. This includes five plain bowls, two with opposed lip tabs, a small plain jar or cup (Figure 3c), seven plain jars or bottles, a Bois d'Arc Plain, var. Crawford bowl with a scalloped and cut lip (Figure 3a) (Perttula et al. 2016), an effigy bowl with a bird head at one end and a tab tail at the other end of the bowl, a punctated jar with strap handles (probably Monkstown Fingernail Impressed), a Sanders Engraved carinated bowl (Figure 3d) with diagonally opposed engraved lines, and two engraved water bottles. The first bottle is decorated with a series of narrow vertical engraved zones filled with cross-hatched lines (Figure 3b), while the second bottle - with a carinated body — has two sets of concentric engraved diamonds or circles on the vessel body, along with a single row of engraved pendant triangles at the top of the vessel body (Figure 3e).

\section{SUMMARY AND CONCLUSIONS}

41FK97 is a large ancestral Caddo site in the Big Cypress Creek basin, first discovered and investigated by an artifact collector in the early 1990s; different parts of the site were officially recorded in 1997 and 2010 during the survey of proposed improvements to SH 37 and in the archaeological survey of the proposed Keystone XL pipeline right-of-way. Two areas of the site - both apparently outside of the proposed SH 37 and pipeline right-of-ways - are known to have ancestral Caddo burials, eight burials in Area 1 and two burials in Area 2.

The eight burials in Area 1 that were investigated by the artifact collector were in east-west oriented graves with the individuals (both children and adults) laid in the graves in an extended supine position. One of the burials had a clay pipe (form unknown), and a total of 19 vessels had been placed as funerary offerings with the deceased individuals. More than 73 percent of the ceramic vessels are plain bowls, jars, or bottles, including a distinctive Bois d'Arc Plain, var. Crawford bowl. This variety of Bois d'Arc Plain is common in Middle Caddo period burial features at the Sanders site (41LR2) on the Red River. Sanders Engraved carinated bowl are also a common funerary offering in burial features at the Sanders site. The two engraved bottles share decorative elements on several of the bottles and other fine ware vessels from the Sanders site (Perttula et al. 2016), including cross-hatched elements as well as diamonds and concentric circles. 


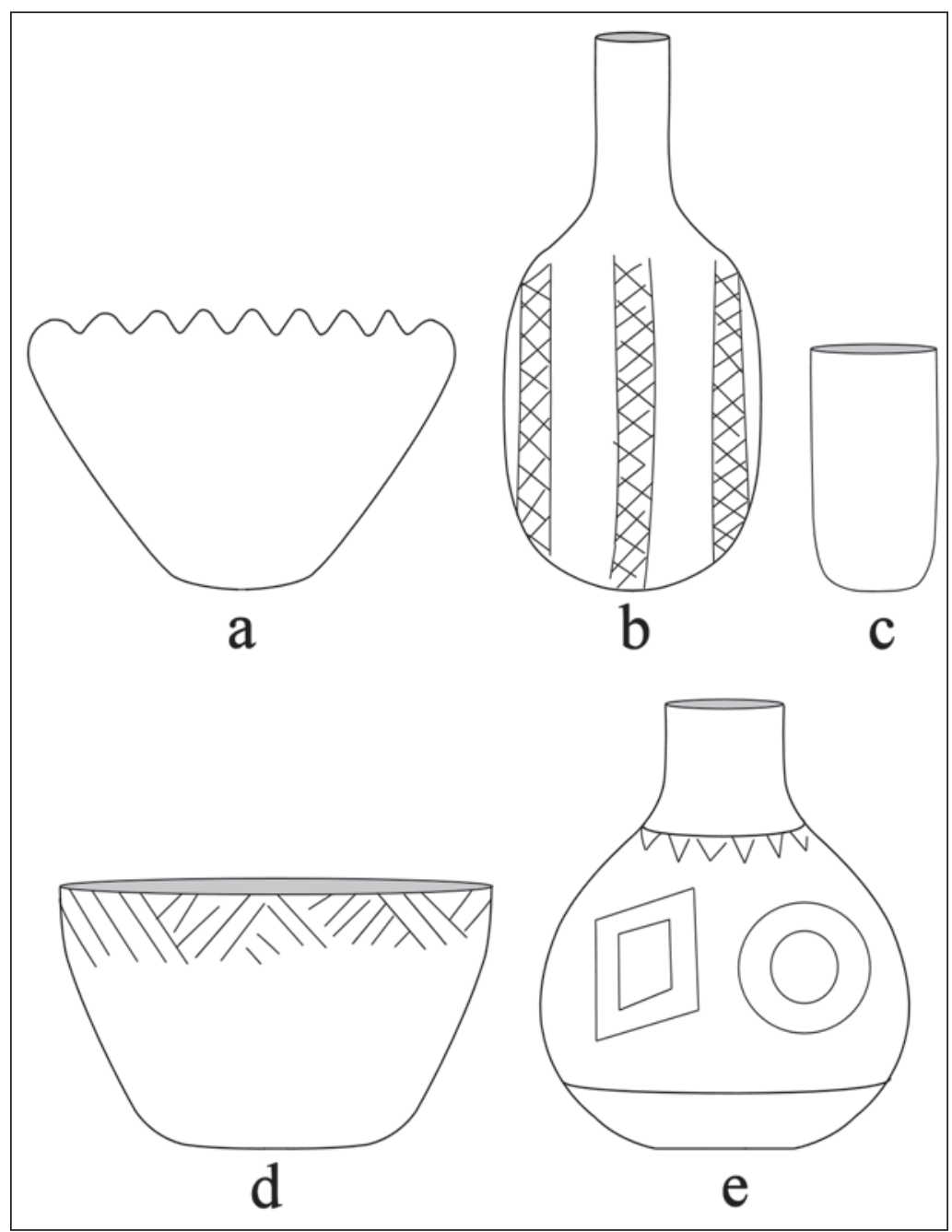

Figure 3. Drawings of selected ceramic vessels in the ancestral Caddo cemetery at 41FK97.

Overall, the character of the ceramic vessels in the burials from Area 1 at 41FK97 suggest that they are from a Middle Caddo period cemetery dating from ca. A.D. 1200-1400. Thus, the cemetery is contemporaneous with the Sanders phase occupation of the Red River and upper Sabine River basins, and with several other Middle Caddo sites and cemeteries in the western part of the Big Cypress Creek basin (Nelson and Turner 1997:1, 5 and Figure 1).

\section{ACKNOWLEDGMENTS}

Sandra Hannum and Lance Trask prepared the figures in this article. Thanks to Jean Hughes for information on Texas Archeological Research Laboratory procedures regarding assigning site trinomials. 


\section{REFERENCES CITED}

Carpenter, S., K. Miller, J. D. Lowe, N. Crumbley, J. Steely, A. Tremblay, A. Mod, K. Lawrence, J. McGilvray, J. Barrera, L. I. Acuna, J. Cooper, C. Higgins, R. Byerly, J. Long, V. Zietz, M. Delmas, C. Riordan, L. Kester, L. Benson, N. Boyer, E. Salisbury, N. Klitzka, S. Baer, C. Berg, T. Witt, S. Doyle, T. K. Perttula, and K. Reed

2010 Cultural Resource Inventory of the Keystone XL Pipeline Project: Gulf Coast Segment in Texas, Angelina, Cherokee, Delta, Fannin, Franklin, Hardin, Hopkins, Jefferson, Lamar, Liberty, Nacogdoches, Orange, Polk, Rusk, Smith, Upshur, and Wood Counties, Texas. SWCA Cultural Resources Report No. 2008-392, SWCA Environmental Consultants, Austin.

Nelson, B. and M. Turner

1997 Middle Caddoan Sites in the Cypress Creek Drainage Basin. Journal of Northeast Texas Archaeology 10:1-11.

Perttula, T. K., M. Walters, and B. Nelson

2016 Caddo Ceramic Vessels from the T. M. Sanders Site (41LR2) on the Red River in Lamar County, Texas. Special Publication No. 41. Friends of Northeast Texas Archaeology, Austin and Pittsburg.

Thurmond, J. P.

1990 Archeology of the Cypress Creek Drainage Basin, Northeastern Texas and Northwestern Louisiana. Studies in Archeology 5. Texas Archeological Research Laboratory, The University of Texas at Austin. 